\title{
Comprehensive Evaluation and Research of the Education APP Based on AHP \\ Wu-Yu WANG ${ }^{1, a}$, Hai-Qi FENG ${ }^{2, b}$ \\ 1, 2 No.39th of South College Road, Beijing 100081, China \\ a717212398@qq.com, b hq_feng@126.com
}

Keywords: Education, APP, The analytic hierarchy process, Evaluation.

\begin{abstract}
This paper, based on related research on education APP, established the evaluation index system of the corresponding index weight, using the analytic hierarchy process (AHP) and focusing on the education of learning APP, then created the education quality evaluation model of the APP. The study found that the evaluation index system of the education of APP based on the AHP was not only able to assess the situation and competitiveness of the current education APP, but also could promote the efficient education develop in the age of the Internet.
\end{abstract}

\section{Introduction}

APP is the application that runs on the mobile terminal device. With the rapid development of mobile information technology and the popularity of mobile devices, education APP get vigorous development, promoting the education mode of innovation and development, which is a great opportunity to deep the education reform and improve the mechanism of the education.

So far, the research methods and angles of educational app are various at home and abroad. Yanlin Zheng \& Li Lou (2010) fully grasped the characteristics of mobile learning and made a research on the design of the mobile learning under the SECI model, and they pointed out that the design emphasis of mobile learning resources is the "knowledge", "situation", "humanized design" and "interactive" design. Gang Cheng (2014) built the appraisal model of mobile learning resources, and put forward an evaluation framework user perspective, focusing on 40 top class learning resources in APP store. Qingtang Liu (2016) discussed the design scheme from mobile learning resources, human-computer interaction, interface layout, and other aspects, also, they explored and realized the interaction design of mobile learning resources on the basis of some actual cases. From the content of education APP building, management and marketing, as well as the education APP mode, Yuhui Ma and Le Zhao (2016) expounded the development of education APP mode and put forward suggestions on the development of education APP. Chi Zhang and Chen gang obtained ideal clustering results by making use of the data mining technology, and then analyzed the episodic learning resource feasibility and the specific design strategy in mobile learning. Qinglong Zhan and Meizhu Yuan (2009) constructed a mobile learning resources quality house model which was based on the needs of learners and they also found that the elements to improve quality. Based on the mobile learning application evaluation framework ,Tao Wang (2013) organized a lot of mobile learning related evaluation index factors, and with reference to the evaluation principle, they classified, combed and optimized these indicators, finally formed a set of evaluation index system.

Although many scholars have conducted a multi-angle and multi-level research on education app, when users face different and various quality of education app, how to choose a suitable app, is still a difficult problem. Therefore, it is of great theoretical and practical significance to explore a more reasonable and effective evaluation method of educational app. Based on the results of previous studies, this paper constructs an evaluation method of educational app on the basis of AHP, and applies it to the comprehensive evaluation of some educational apps. It is hoped that this study will provide useful reference for the healthy development of educational app and mobile education 


\section{Study Design}

The evaluation of educational app involves many subjective and objective factors, including multiple indicators of multiple levels. Combining with the current development situation and research results of educational app at home and abroad, using analytic hierarchy process ( AHP ) as the main evaluation method, not only simplifies the whole evaluation process, but also makes the overall evaluation of the whole has a sufficient basis.

\section{The Selection of Evaluation Index}

In order to determine the main factors of educational impact of app, this paper, from the perspective of user experience, through some market surveys, referring to the relevant literature materials, summed up the key elements, and compiled a comprehensive evaluation index system of education app. The system is divided into three levels, namely the target layer, the first level index layer and the second level index layer. The goal is to make the overall assessment more clear and to be able to respond to the reality of an educational app. Under the target level, two levels are also constructed: (1) First-level indicator layer: Usability is to measure the effectiveness of educational app after the use of the application, it is the reliability, stability and functional comprehensive characteristics of the equipment; Content refers to the design of learning resources quality and teaching knowledge system of the whole educational app; Security includes the security of some personal information data when users use an educational app, and the security of mobile terminal used by users; Interactivity is whether the user can really make full use of a certain education app, and can use it as a tool to effectively improve their knowledge level; Profitability refers to whether an educational app can bring benefits to its enterprises, which is not only the profit, but also the popularity of enterprises, the establishment of enterprise partners, and so on.(2) Second-level indicator layer: running speed, stability, interface aesthetics, capacity, accuracy, timeliness, diversity, security policy, real-name authentication, confidentiality, download rate, rate of user registration, interactive learning rate, income growth, Percentage of paid users and advertisement.

\section{Comprehensive Quality Evaluation Index System OF Educational App}

Based on the AHP method, the important factors that affect the comprehensive quality of education app are stratified. The hierarchy and specific explanation of each indicator are shown in table 1. 
Table 1: Comprehensive quality evaluation index system of educational app

\begin{tabular}{|c|c|c|c|c|c|c|}
\hline \multicolumn{2}{|c|}{$\begin{array}{l}\text { Target } \\
\text { layer }\end{array}$} & \multicolumn{2}{|c|}{$\begin{array}{l}\text { First-level } \\
\text { indicator layer }\end{array}$} & \multicolumn{2}{|l|}{$\begin{array}{l}\text { Second-level } \\
\text { indicator layer }\end{array}$} & \multirow{2}{*}{$\begin{array}{l}\text { Indicator interpretation } \\
\text { The response of app, } \\
\text { including execution } \\
\text { service, request service }\end{array}$} \\
\hline \multirow{16}{*}{ 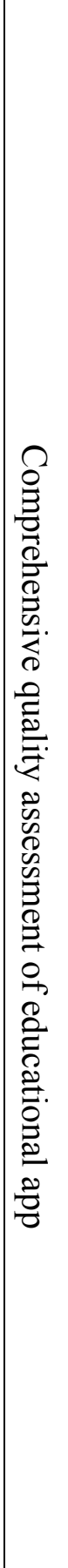 } & \multirow{16}{*}{$\mathrm{U}$} & \multirow{3}{*}{ Usability } & \multirow{3}{*}{ U1 } & Running speed & U11 & \\
\hline & & & & Stability & U12 & $\begin{array}{l}\text { Whether there is flash } \\
\text { back, card, not }\end{array}$ \\
\hline & & & & $\begin{array}{l}\text { Interface } \\
\text { aesthetics }\end{array}$ & U13 & $\begin{array}{l}\text { The appearance of app } \\
\text { and the beauty of }\end{array}$ \\
\hline & & \multirow{4}{*}{ Content } & \multirow{4}{*}{$\mathrm{U} 2$} & Capacity & U21 & $\begin{array}{l}\text { The number of resources } \\
\text { stored in the database } \\
\text { for different types of }\end{array}$ \\
\hline & & & & Accuracy & $\mathrm{U} 22$ & $\begin{array}{l}\text { Whether there are any } \\
\text { errors, such as spelling, }\end{array}$ \\
\hline & & & & Timeliness & U23 & $\begin{array}{l}\text { Speed of learning } \\
\text { content update in }\end{array}$ \\
\hline & & & & Resources & $\mathrm{U} 24$ & $\begin{array}{l}\text { Different forms of } \\
\text { learning that app can }\end{array}$ \\
\hline & & \multirow{3}{*}{ Security } & \multirow{3}{*}{ U3 } & Security policy & U31 & $\begin{array}{l}\text { Education app is } \\
\text { protected by security }\end{array}$ \\
\hline & & & & $\begin{array}{l}\text { Real-name } \\
\text { authentication }\end{array}$ & U32 & $\begin{array}{l}\text { The proportion of users } \\
\text { with real-name } \\
\text { authentication accounts }\end{array}$ \\
\hline & & & & Confidentiality & U33 & $\begin{array}{l}\text { The degree of user } \\
\text { information protection } \\
\text { after removing the }\end{array}$ \\
\hline & & \multirow{3}{*}{ Interactivity } & \multirow{3}{*}{ U4 } & Download rate & U41 & $\begin{array}{l}\text { Frequency of downloads } \\
\text { of educational apps }\end{array}$ \\
\hline & & & & $\begin{array}{l}\text { User } \\
\text { registration } \\
\text { rate }\end{array}$ & U42 & $\begin{array}{l}\text { The ratio of user } \\
\text { registration to the total } \\
\text { user of the app on app }\end{array}$ \\
\hline & & & & $\begin{array}{l}\text { Interactive } \\
\text { learning rate }\end{array}$ & U43 & $\begin{array}{l}\text { Frequency of interaction } \\
\text { between users using app }\end{array}$ \\
\hline & & \multirow{3}{*}{ Profitability } & \multirow{3}{*}{ U5 } & Income growth & U51 & $\begin{array}{l}\text { The annual average } \\
\text { profit growth rate }\end{array}$ \\
\hline & & & & $\begin{array}{l}\text { Percentage of } \\
\text { paid users }\end{array}$ & U52 & $\begin{array}{l}\text { Proportion of users paid } \\
\text { for value-added services }\end{array}$ \\
\hline & & & & Advertisement & U53 & $\begin{array}{l}\text { The average frequency } \\
\text { of educational app spots } \\
\text { per hour }\end{array}$ \\
\hline
\end{tabular}

\section{Establishment of Evaluation Model}

For different target customers, the judgment matrix and the weight calculation are different. Depending on the purpose of the customer using the app, the target customer can be divided into three categories: Developer, market users and learner. The development class users who engaged in the development and design education app pay more attention to the application performance of education app. Market class users who invest in the app want to get more benefits from the education app, so they care more about the profitability of the education app. And for learners, they 
want to learn more useful knowledge through education app to improve themselves, so they value the content of education app. This paper mainly focuses on the learners to establish the evaluation model.

\section{Weight Calculation and Consistency Check}

We invited 10 experts, including experienced teachers in universities, years of senior education experts and scholars in different fields of education, who composed of experts group, through the literature review and expert discussion, finally obtained the comprehensive judgment matrix.

Table 2: Education app comprehensive quality U judgment matrix

\begin{tabular}{|c|c|c|c|c|c|c|}
\hline U & U1 & U2 & U3 & U4 & U5 & Wi \\
\hline U1 & 1 & 1 & 1 & 2 & 2 & 0.247 \\
\hline U2 & 1 & 1 & 1 & 3 & 2 & 0.268 \\
\hline U3 & 1 & 1 & 1 & 2 & 2 & 0.247 \\
\hline U4 & $1 / 2$ & $1 / 3$ & $1 / 2$ & 1 & 1 & 0.113 \\
\hline U5 & $1 / 2$ & $1 / 2$ & $1 / 2$ & 1 & 1 & 0.124 \\
\hline
\end{tabular}

Consistency ratio of judgment matrices: $\mathrm{CR}=0.004<1$

Weight relative to the target: 1

Table 3: Availability U1 judgment matrix

\begin{tabular}{|c|c|c|c|c|}
\hline U1 & U11 & U12 & U13 & Wi \\
\hline U11 & 1 & 2 & 3 & 0.540 \\
\hline U12 & $1 / 2$ & 1 & 2 & 0.297 \\
\hline U13 & $1 / 3$ & $1 / 2$ & 1 & 0.163 \\
\hline
\end{tabular}

Consistency ratio of judgment matrices: $\mathrm{CR}=0.009<0.1$

The weight of usability: 0.247

Table 4: Content U2 judgment matrix

\begin{tabular}{|c|c|c|c|c|c|}
\hline U2 & U21 & U22 & U23 & U24 & Wi \\
\hline U21 & 1 & $1 / 3$ & $1 / 2$ & $1 / 3$ & 0.108 \\
\hline U22 & 3 & 1 & 2 & 2 & 0.413 \\
\hline U23 & 2 & $1 / 2$ & 1 & $1 / 2$ & 0.187 \\
\hline U24 & 3 & $1 / 2$ & 2 & 1 & 0.292 \\
\hline
\end{tabular}

Consistency ratio of judgment matrices: $\mathrm{CR}=0.026<0.1$

The weight of content: 0.268

Table 5: Security U3 judgment matrix

\begin{tabular}{|c|c|c|c|c|}
\hline U3 & U31 & U32 & U33 & Wi \\
\hline U31 & 1 & $1 / 2$ & $1 / 3$ & 0.163 \\
\hline U32 & 2 & 1 & $1 / 2$ & 0.297 \\
\hline U33 & 3 & 2 & 1 & 0.540 \\
\hline
\end{tabular}

Consistency ratio of judgment matrices: $\mathrm{CR}=0.008<0.1$

The weight of security: 0.247 
Table 6: Interactivity U4 judgment matrix

\begin{tabular}{|c|c|c|c|c|}
\hline U4 & U41 & U42 & U43 & Wi \\
\hline U41 & 1 & 1 & $1 / 3$ & 0.240 \\
\hline U42 & 1 & 1 & $1 / 2$ & 0.266 \\
\hline U43 & 3 & 2 & 1 & 0.494 \\
\hline
\end{tabular}

Consistency ratio of judgment matrices: $\mathrm{CR}=0.046<0.1$

The weight of interactivity: 0.113

Table 7: Profitability U5 judgment matrix

\begin{tabular}{|c|c|c|c|c|}
\hline U5 & U51 & U52 & U53 & Wi \\
\hline U51 & 1 & 2 & 3 & 0.540 \\
\hline U52 & $1 / 2$ & 1 & 2 & 0.297 \\
\hline U53 & $1 / 3$ & $1 / 2$ & 1 & 0.163 \\
\hline
\end{tabular}

Consistency ratio of judgment matrices: $\mathrm{CR}=0.008<0.1$

The weight of profitability: 0.124

According to the above calculation and analysis, the CR value of all judgment matrices is less than 0.10 , which shows that all the judgment matrix consistency checking is adopted and the acceptability is very high.

\section{Weight of Quality Assessment Index}

According to the calculation of the weights of two levels, these weights are processed and calculated, and the specific weight values of each secondary index relative to the overall target can be obtained, as shown in table 8 .

Based on the calculation results, (1)the weights of first level indicator usability U1, content U2, security u3, interactivity U4 and security U5 are respectively $(0.247,0.268,0.247,0.113$, 0.124 ), so the orders is U2、U1、U3、U5、U4; (2) The relative weights of the second order index u11-u53 are respectively $(0.133,0.073,0.04,0.029,0.111,0.05,0.078,0.04,0.073,0.133$, $0.027,0.03,0.056,0.067,0.037,0.02)$, the order is: running speed, confidentiality, accuracy, diversity, stability, real-name authentication, income growth, interactive learning rate, timeliness, interface aesthetics, security policy, percentage of paid users, user registration rate, capacity, download rate and advertisement. 
Table 8: Total weight of education app comprehensive evaluation index

\begin{tabular}{|c|c|c|c|c|c|c|}
\hline & $\begin{array}{c}\text { Usability } \\
\text { U1 } \\
0.247 \\
\end{array}$ & $\begin{array}{c}\text { Content } \\
\text { U2 } \\
0.268 \\
\end{array}$ & $\begin{array}{c}\text { Security } \\
\text { U3 } \\
0.247 \\
\end{array}$ & $\begin{array}{c}\text { Interactivity } \\
\mathrm{U} 4 \\
0.113 \\
\end{array}$ & $\begin{array}{c}\text { Profitability } \\
\text { U5 } \\
0.124 \\
\end{array}$ & $\begin{array}{c}\text { Weight } \\
\mathrm{W}_{\mathrm{ij}}\end{array}$ \\
\hline $\begin{array}{l}\text { Running speed } \\
\text { U11 }\end{array}$ & 0.540 & & & & & 0.133 \\
\hline Stability U12 & 0.297 & & & & & 0.073 \\
\hline $\begin{array}{l}\text { Interface } \\
\text { aesthetics U13 }\end{array}$ & 0.163 & & & & & 0.040 \\
\hline Capacity U21 & & 0.108 & & & & 0.029 \\
\hline Accuracy U22 & & 0.413 & & & & 0.111 \\
\hline Timeliness U23 & & 0.187 & & & & 0.050 \\
\hline Resources U24 & & 0.292 & & & & 0.078 \\
\hline $\begin{array}{l}\text { Security policy } \\
\text { U31 }\end{array}$ & & & 0.163 & & & 0.040 \\
\hline $\begin{array}{l}\text { Real-name } \\
\text { authentication } \\
\text { U32 }\end{array}$ & & & 0.297 & & & 0.073 \\
\hline $\begin{array}{l}\text { Confidentiality } \\
\text { U33 }\end{array}$ & & & 0.540 & & & 0.133 \\
\hline $\begin{array}{l}\text { Download rate } \\
\text { U41 }\end{array}$ & & & & 0.240 & & 0.027 \\
\hline $\begin{array}{l}\text { User } \\
\text { registration rate } \\
\text { U42 }\end{array}$ & & & & 0.266 & & 0.030 \\
\hline $\begin{array}{l}\text { Interactive } \\
\text { learning rate } \\
\text { U43 }\end{array}$ & & & & 0.494 & & 0.056 \\
\hline $\begin{array}{l}\text { Income growth } \\
\text { U51 }\end{array}$ & & & & & 0.540 & 0.067 \\
\hline $\begin{array}{l}\text { Percentage of } \\
\text { paid users U52 }\end{array}$ & & & & & 0.297 & 0.037 \\
\hline $\begin{array}{l}\text { Advertisement } \\
\text { U53 }\end{array}$ & & & & & 0.163 & 0.020 \\
\hline
\end{tabular}

\section{Evaluation Model}

The weight of different indexes can be obtained by analytic hierarchy process, so the comprehensive quality evaluation model of education app can be established, in which the comprehensive quality coefficient of an educational app expressed by $\mathrm{Zi}$, Wij represents the weight of the indicator $\mathrm{Uij}$, aij represents the specific value of indicator $\mathrm{Uij}$.

$$
Z_{i}=\mathrm{b}+\mathrm{a}_{11} * \mathrm{~W}_{11}+\mathrm{a}_{12} * \mathrm{~W}_{12}+\mathrm{a}_{13} * \mathrm{~W}_{13}+\mathrm{a}_{21} * \mathrm{~W}_{21}+\mathrm{a}_{22} * \mathrm{~W}_{22}+\mathrm{a}_{23} * \mathrm{~W}_{23}+\mathrm{a}_{24} *
$$

$\mathrm{W}_{24}+\mathrm{a}_{31} * \mathrm{~W}_{31}+\mathrm{a}_{32} * \mathrm{~W}_{32}+\mathrm{a}_{33} * \mathrm{~W}_{33}+\mathrm{a}_{41} * \mathrm{~W}_{41}+\mathrm{a}_{42} * \mathrm{~W}_{42}+\mathrm{a}_{43} * \mathrm{~W}_{43}+\mathrm{a}_{51} * \mathrm{~W}_{51}+$ $\mathrm{a}_{52} * \mathrm{~W}_{52}+\mathrm{a}_{53} * W_{53}$

According to the numerical analysis, we can get the comprehensive quality evaluation model of educational app:

$\mathrm{Z}_{\mathrm{i}}=\mathrm{b}+\mathrm{a}_{11} * 0.133+\mathrm{a}_{12} * 0.073+\mathrm{a}_{13} * 0.040+\mathrm{a}_{21} * 0.029+\mathrm{a}_{22} * 0.111+\mathrm{a}_{23} * 0.05+$

$\mathrm{a}_{24} * 0.078+\mathrm{a}_{31} * 0.040+\mathrm{a}_{32} * 0.073+\mathrm{a}_{33} * 0.133+\mathrm{a}_{41} * 0.027+\mathrm{a}_{42} * 0.03+\mathrm{a}_{43} *$ $0.056+\mathrm{a}_{51} * 0.067+\mathrm{a}_{52} * 0.037+\mathrm{a}_{53} * 0.02$ 


\section{Application of Evaluation Model}

In the Android app store, the top 10 educational apps ranked relatively high in the education app are studied as samples. In order to protect the privacy of each app, the anonymous method is used to carry on the empirical study. The raw data of the quantitative indexes collected is obtained through the "octopus data collector ", which comes from the" IT oranges " website, the" jiemodui " website, the" applied radar " website and the" master cicadas " website. The data is normalized according to formula $\mathrm{X}=(\mathrm{Xi}-\mathrm{Xmin}) /(\mathrm{X} \max -\mathrm{Xmin})$, however, some quantitative index data relate to the privacy information of some enterprises, is difficult to collect. Therefore, this paper uses some quantitative indicators as qualitative indicators to deal with, and collect data through questionnaire survey.

For qualitative indicators and some quantitative index data difficult to collect, this paper designed a relative survey questionnaire, stipulating that the users of the questionnaire must use the app personally, otherwise the questionnaire cannot be completed. From January 2017 to February 2017, using the " Wenjuanxing" platform, 100 questionnaires were issued for each app based on the " Wenjuanxing" platform. a total of 1000 questionnaires were issued, 823 were recycled, 768 were valid questionnaires, and the recovery rate was $82.3 \%$, and the effective rate was $93.32 \%$.

$$
\begin{aligned}
& \mathrm{M} 1=84 * 0.133+86 * 0.073+87 * 0.040+89 * 0.029+85 * 0.111+88 * 0.05+80 \\
& * 0.078+80 * 0.040+75 * 0.073+86 * 0.133+90 * 0.027+77 * 0.03+85 \\
& * 0.056+85 * 0.067+72 * 0.037+76 * 0.02=83.849 \\
& \mathrm{M} 2=89 * 0.133+87 * 0.073+86 * 0.040+89 * 0.029+89 * 0.111+90 * 0.05+80 * \\
& 0.078+80 * 0.040+76 * 0.073+87 * 0.133+93 * 0.027+82 * 0.03+88 * \\
& 0.056+85 * 0.067+70 * 0.037+73 * 0.02=84.791 \\
& \mathrm{M} 3=80 * 0.133+81 * 0.073+84 * 0.040+84 * 0.029+80 * 0.111+79 * 0.05+78 \\
& * 0.078+80 * 0.040+73 * 0.073+83 * 0.133+85 * 0.027+83 * 0.03+80 \\
& * 0.056+80 * 0.067+64 * 0.037+77 * 0.02=79.364 \\
& \mathrm{M} 4=87 * 0.133+86 * 0.073+88 * 0.040+88 * 0.029+85 * 0.111+91 * 0.05+80 \\
& * 0.078+80 * 0.040+74 * 0.073+86 * 0.133+92 * 0.027+80 * 0.03+86 \\
& * 0.056+86 * 0.067+73 * 0.037+77 * 0.02=83.889 \\
& \mathrm{M} 5=85 * 0.133+83 * 0.073+87 * 0.040+85 * 0.029+84 * 0.111+86 * 0.05+86 \\
& * 0.078+80 * 0.040+75 * 0.073+85 * 0.133+90 * 0.027+76 * 0.03+89 \\
& * 0.056+83 * 0.067+71 * 0.037+74 * 0.02=82.983 \\
& \text { M6 }=86 * 0.133+86 * 0.073+88 * 0.040+87 * 0.029+82 * 0.111+85 * 0.05+84 * \\
& 0.078+80 * 0.040+73 * 0.073+86 * 0.133+91 * 0.027+74 * 0.03+84 * \\
& 0.056+86 * 0.067+70 * 0.037+72 * 0.02=82.803 \\
& \mathrm{M} 7=87 * 0.133+85 * 0.073+88 * 0.040+93 * 0.029+95 * 0.111+92 * 0.05+85 \\
& * 0.078+80 * 0.040+75 * 0.073+90 * 0.133+96 * 0.027+82 * 0.03+88 \\
& * 0.056+90 * 0.067+71 * 0.037+80 * 0.02=86.650 \\
& \mathrm{M} 8=85 * 0.133+85 * 0.073+85 * 0.040+89 * 0.029+83 * 0.111+83 * 0.05+83 \\
& * 0.078+80 * 0.040+70 * 0.073+88 * 0.133+88 * 0.027+75 * 0.03+82 \\
& * 0.056=82.405 \\
& \text { M9 }=83 * 0.133+84 * 0.073+83 * 0.040+84 * 0.029+83 * 0.111+82 * 0.05+80 \\
& * 0.078+80 * 0.040+70 * 0.073+82 * 0.133+86 * 0.027+85 * 0.03+82 \\
& * 0.056+81 * 0.067+69 * 0.037+74 * 0.02=80.620 \\
& \mathrm{M} 10=90 * 0.133+86 * 0.073+88 * 0.040+87 * 0.029+90 * 0.111+91 * 0.05+82 \\
& * 0.078+80 * 0.040+78 * 0.073+88 * 0.133+93 * 0.027+80 * 0.03+92 \\
& * 0.056+88 * 0.067+70 * 0.037+75 * 0.02=85.874
\end{aligned}
$$


Table 9: Comprehensive quality comparison of 10 samples

\begin{tabular}{|c|c|c|}
\hline $\begin{array}{l}\text { Educational } \\
\text { app name }\end{array}$ & $\begin{array}{c}\text { Comprehensive } \\
\text { quality score }\end{array}$ & Ranking \\
\hline M7 & 86.650 & 1 \\
\hline M10 & 85.874 & 2 \\
\hline M2 & 84.791 & 3 \\
\hline M4 & 83.889 & 4 \\
\hline M1 & 83.849 & 5 \\
\hline M5 & 82.983 & 6 \\
\hline M6 & 82.803 & 7 \\
\hline M8 & 82.405 & 8 \\
\hline M9 & 80.620 & 9 \\
\hline M3 & 79.364 & 10 \\
\hline
\end{tabular}

The evaluation results of this paper are consistent with the results of the current major websites, which shows that the education app evaluation model established in this paper is reasonable and feasible.

\section{Conclusion and Suggestion}

In this paper, the weight of each index is calculated by analytic hierarchy process ( AHP ), and the comprehensive quality evaluation model of educational app is established. Through the above analysis, we know that usability, content, security, interactivity and profitability are important factors that affect the comprehensive quality of education app. Through the analysis of the AHP method, we determine the main factors affecting the education app, they are usability, content and security.

Therefore, we give some suggestions from the following aspects to improve the comprehensive quality of educational app and its core competitiveness: Firstly, enhance the technical support of educational app to make it run more smoothly. Because in this information technology age, each app needs to have a good technical foundation to support, to ensure the smooth operation of education app. Secondly, enrich the resources content of educational app and resource types, give users more choice. The difference between educational app and other apps is that it focuses on learning and education, so in order to improve the core competitiveness of education app, it is necessary to enrich the types of educational resources and optimize the quality of learning resources so that all users can really benefit from the use of education app. Thirdly, strengthen the security facilities protection of app to prevent the leakage of user personal information data. The current security design of many educational apps is not mature, so users must ensure that users use the security of the app to ensure that the phone or tablet is not affected by the use of an educational app, and that users will not be compromised after the education app is registered.

\section{References}

[1] Nicole Hennig. Mobile Learning Trends: Accessibility, Ecosystems, Content Creation, J. Library Technology Reports, 2016, 52(3): 4-37.

[2] Ferial Khaddage, Wolfgang Müller. Advancing Mobile Learning in Formal And Informal Settings via Mobile App Technology, J. Educational Technology \& Society, 2015, 19 (3): 16-26.

[3] Yanlin Zheng, Luyi Li. SECI model perspective of mobile learning resources design study, J. Journal of distance education, 2010, (4): 21-34.

[4] Hui Gao. Research on the design of mobile learning resources from the perspective of SECI model, J. Journal of modern distance education, 2014, 151(1): 43-73.

[5] Qingtang Liu, Dandan Xiang for 3 g mobile phone design and implementation of mobile 
learning resources interaction , J. China audio-visual education, 2012, 22 (11) : 59-71.

[6] Yuhui Ma, Le Zhao. New mobile learning resources - education APP development model to explore, J. China audio-visual education, ploidy of 2016 (4) : 60-80.

[7] Chi Zhang, Gang Chen. Design of episodic learning resources in the mobile learning research, J. Open education research, 2009, 15 (3): 67-72.

[8] QingLong Zhan, Meizhu Yuan, Construction of quality house model of mobile learning resources construction, J. China audio-visual education, 2009, 273; 51-56.

[9] Tao Wang. Design and research of mobile learning multidimensional evaluation framework, D. Beijing: Beijing University of posts and telecommunications, 2013. 